\title{
SKLADNICE ZBIORÓW PRUSKIEJ BIBLIOTEKI PAŃSTWOWEJ NA DOLNYM ŚLĄSKU W CZASIE II WOJNY ŚWIATOWEJ
}

Mimo że od zakończenia II wojny światowej minęło ponad 70 lat, to problematyka związana $\mathrm{z}$ rewindykacją i zabezpieczeniem dóbr kultury przemieszczonych w latach czterdziestych XX w. w dalszym ciągu wymaga gruntownych badań i analiz. Jednym z przykładów niezadowalającego stanu wiedzy w tym zakresie są losy zbiorów Pruskiej Biblioteki Państwowej, które w czasie wojny zostały przeniesione - z zagrożonego bombardowaniami Berlina - do prowincjonalnych składnic na terenie III Rzeszy. W wyniku postanowień Konferencji Poczdamskiej - mającej na celu omówienie trybu i sposobu likwidacji skutków wojny oraz wypracowanie modelu organizacji powojennej Europy - część obszarów, na których znalazły się zasoby berlińskiej biblioteki, trafiły pod polską administrację. Skutkiem tych decyzji było przejęcie przez naszych urzędników zarządu nad mieniem kulturalnym tzw. Ziem Zachodnich (lub Ziem Odzyskanych). Wydawałoby się więc, że los tych zasobów powinien być dość dobrze udokumentowany i zbadany. W przypadku zbiorów Pruskiej Biblioteki Państwowej - które po wojnie znalazły się w polskich rękach - sytuacja wygląda zupełnie inaczej. Do dziś tę kolekcję - nazywaną potocznie „Berlinką” - identyfikuje się wyłącznie z depozytem przechowywanym w krakowskiej Bibliotece Jagiellońskiej. Nic zresztą dziwnego - zasób ten obejmuje ponad pół miliona archiwaliów, wśród których są średniowieczne rękopisy, modlitewniki, autografy muzyczne (w tym Bacha, Beethovena, Brahmsa, Busoniego, Haydna, Loewego, Mendelssohna, Meyerbeera, Mozarta, Schuberta, Schumanna, Paganiniego, Telemanna, Wolffa) oraz listy i inne prywatne dokumenty Goethego, braci Grimm, Lutra, Herdera, Hegla czy Kalwina. Nie wiele osób jednak wie, że wymieniony zasób pochodzi z jednej tylko składnicy - utworzonej w Krzeszowie na Dolnym Śląsku. Stanowi więc tylko fragment zbiorów Pruskiej Biblioteki Państwowej odnalezionych po wojnie na terenach przyłączonych do Polski. Dalsze badania tej tematyki - w zakresie losu zasobów berlińskiej biblioteki ewakuowanych na Dolny Śląsk - wskazują na szersze spektrum i złożoność tego zagadnienia. W celu jego przeanalizowania autor skorzystał z materiałów źródłowych (w tym korespondencji między dyrekcją Pruskiej Biblioteki Państwowej a konserwatorem zabytków prowincji Dolnego Śląska i właścicielami obiektów, które wykorzystano na składnice ewakuowanych zasobów - zachowanych w Herder-Institut für historische Ostmitteleuropaforschung - oraz przechowywanej w National Archives and Records Administration w Waszyngtonie dokumentacji alianckich służb śledczych 
odpowiedzialnych po wojnie za zabezpieczenie dóbr kultury) oraz nielicznych opracowań (obcych i polskich) poświęconych losom Pruskiej Biblioteki Państwowej w czasie II wojny światowej.

Rozpoczynając omawianie problemu stanowiącego temat niniejszego opracowania warto zarysować proces przygotowań niemieckich instytucji kulturalnych do ochrony swoich zbiorów na wypadek wybuchu wojny. Działania te rozpoczęto już w pierwszej połowie lat trzydziestych XX w. - zanim jeszcze ktokolwiek zaczął poważnie traktować dążenia III Rzeszy do dominacji nad światem. Już w 1934 r. minister nauki i oświaty, dr Bernhard Rust (szef Ministerstwa Nauki, Wychowania i Oświaty Rzeszy - Reichsministerium für Wissenschaft, Erziehung und Volksbildung), wydał zarządzenie, zgodnie z którym dyrektorzy placówek muzealnych, bibliotek i archiwów zobligowani zostali do przygotowania planu działań mających na celu ochronę niemieckiego dziedzictwa kultury. Jedną z pierwszych instytucji, która podjęła się tego zadania był urząd Dyrektora Generalnego Muzeów Państwowych w Berlinie (Generaldirektoren der Staatlichen Museen zu Berlin). Kierujący nią dr Otto Kümmel polecil wykonać dwie listy eksponatów należacych do Muzeum Zamkowego (Schlossmuseum), zawierające wszystkie obiekty, które musiatyby zostać zabezpieczone przed ewentualnymi nalotami bombowymi ${ }^{\mathrm{I}}$. W $1935 \mathrm{r}$. Kümmel otrzymał kolejne zadanie miał nadzorować budowę podziemnego schronu w Brandenburgii, w którym (na wypadek konfliktu zbrojnego) planowano złożyć m.in. zbiory berlińskiego Kaiser Friedrich Museum². Plany budowy tego obiektu zarzucono, ale $\mathrm{w}$ dalszym ciągu pracowano nad strategią ochrony niemieckiego dziedzictwa kultury na wypadek wybuchu wojny. W 1936 r. berliński konserwator zabytków (Provinzialkonservator der Reichshauptstadt) dr Walter Peschke przygotował opracowanie pt. „Ochrona zabytków Berlina” („Denkmalpflege in Berlin”), w którym zaproponował rozwiązania $\mathrm{w}$ zakresie zabezpieczenia zbiorów muzealnych, pomników, a nawet zabytków architektonicznych. Początkowo działania te miały objąć wyłącznie Berlin, ale bardzo szybko uznano, że podobne rozwiązania powinny powstać dla innych obszarów Rzeszy33. Jedną z instytucji, która pierwsza została objęta planami ewakuacyjnymi była Pruska Biblioteka Państwowa (Preussische Staatsbibliothek) - jedna z najznamienitszych placówek kulturalnych Niemiec.

I6 października 1937 r. minister Bernhard Rust przesłał do dyrektora Pruskiej Biblioteki Państwowej - Hugona Andresa Krüssa - zarządzenie regulujące sposób ochrony zbiorów tej instytucji na wypadek wybuchu wojny. Nakładało ono na bibliotekarzy obowiązek inwentaryzacji zasobów pod kątem ich zabezpieczenia i przygotowania do ewentualnej ewakuacji ze stolicy. Rok później dziat rękopisów Pruskiej Biblioteki Państwowej wyselekcjonowat I66 woluminów, które powinny się znaleźć w pierwszej kolejności na liście obiektów objętych szczególnq ochrona ${ }^{4}$. Ze względu na niepokój, jaki zapanował w I938 r. - po aneksji Austrii

\footnotetext{
Raport pracownika berlińskiego Schlossmuseum dr. Roberta Schmidta z 15 X 1945 roku, National Archives and Records Administration (dalej NARA), Records Concerning the Central Collecting Points: Wiesbaden Central Collecting Point, 1945-1952, RG 260.

2 Ch. Norris, The Disaster at Flakturm Friedrichshain; a Chronicle and List of Paintings, „The Burlington Magazine", nr 597/1952, s. 337-347.

3 D. Nellessen, Von Baudenkmälern zu Baudenkmalen. Die Entwicklung des Denkmalrechts im Land Berlin von 1949 bis heute, Berlin 2009.

4 J.M. Kowalski, J.R. Kudelski, R. Sulik, Lista Grundmanna. Tajemnice skarbów Dolnego Ślaska, Warszawa 2015, s. 15.
} 
i Kraju Sudeckiego - rozpoczęto przygotowania do przeniesienia wybranych zasobów w bezpieczne miejsca. Wsparcia dla podjętych działań udzielił Bibliotece minister finansów Johannes Popitz. Hugo Andres Krüss zanotował w swoim dzienniku, że najcenniejsze zbiory biblioteczne postanowiono umieścić w piwnicy ówczesnego banku Disconto-Gesellschaft, a obecnie Ministerstwa Gospodarki Rzeszy. Inne wyselekcjonowane zasoby miały zostać złożone w piwnicy Preussische Staatsbank, mieszczącego się przy Markgrafenstraße i Friedrich-Wilhelm-Universität (Uniwersytet im. Fryderyka Wilhelma) w Berlinie. Szukano również alternatywnych miejsc zdeponowania zbiorów bibliotecznych na niemieckiej prowincji. Innymi regionami, które spełniały wymogi ministerstwa nauki (transport kolejowy i względna bliskość do stolicy) były Dolny Śląsk, Turyngia, Brandenburgia i Pomorze. W kolejnych latach właśnie tam trafiły najcenniejsze zbiory Pruskiej Biblioteki Państwowej. Szczególną rolę w tym względzie odegrał Dolny Śląsk - unikalne zasoby tej instytucji trafiły m.in. do Fürstenstein (Książ) Gießmannsdorf (Gościszów), Gröditzburg (Grodziec), Grüssau (Krzeszów), Fischbach (Karpniki) i Hirschberg (Jelenia Góra). Ewakuację zbiorów berlińskich do wymienionych składnic prowadzono we współpracy z konserwatorem zabytków Dolnego Śląska, prof. Güntherem Grundmannem.

Wiosną I94I r. rozpoczęły się masowe naloty na Berlin. Ponieważ część bomb spadła na archiwum Pruskiej Biblioteki Państwowej, dyrektor tej instytucji podjął decyzję o ewakuacji jej najcenniejszych zbiorów. Planowano wysłać je do pałacu Banz [klasztor benedyktyński], klasztoru Beuron oraz obszernego zamku Książ na Dolnym Ślaskúc. W tej ostatniej miejscowości mieściła się rezydencja rodziny książąt Hochberg von Pless. Po tym jak w I94I r. zachodnie media opublikowały informację, że dwóch potomków tego znamienitego rodu wstąpiło do armii walczących przeciwko Niemcom (jeden w siłach brytyjskich, drugi polskich) zamek został przejęty przez III Rzeszę. Z tego powodu już 29 sierpnia I94I $r$. pojawity się pierwsze rozmowy na temat możliwości utworzenia w zamku Książ trzeciej składnicy. Z uwagi na jego ogrom i masywna konstrukcję miat on stać się schronieniem dla najcenniejszej części zbiorów Pruskiej Biblioteki Państwowej. Za zgoda Ministerstwa Kultury-pod określonymi warunkami-oraz w porozumieniu z Zarządem Księstwa w Waldenburgu [Wałbrzychu] (Io października) rozpoczęty się pierwsze transporty zbiorów (od 27 do 28 października, kolejne od 4 do 6 listopada I94I r.) w połaczeniu z akcja w Beuron i pod kierownictwem Maxa Weisweilera7. Weisweiler wspominał później, że ze względu na opady śniegu wjazd samochodów na teren zamku w Książu był utrudniony. Po krótkotrwałej jeździe pod górę byliśmy zmuszeni odłaczyć druga przyczepę $i$ wjechać z pozostała częścia transportu ${ }^{8}$. Operacja zdeponowania w Książu zbiorów Pruskiej Biblioteki Państwowej zakończyła się jednak sukcesem. Uznano też, że ta lokalizacja może być brana pod uwagę w trakcie ewakuacji kolejnych zasobów tej instytucji. W maju 1942 i marcu 1943 r. Książ odwiedził członek kierownictwa Pruskiej Biblioteki Państwowej Wilhelm Poewe. Dzięki pozytywnym wynikom inspekcji - na przełomie kwietnia i maja I943 r. - do Książa dostarczono kolejne 304 skrzynie manuskryptów. Do zamku planowano także przywieźć kolekcję

\footnotetext{
W. Schochow, Bücherschicksale: Die Verlagerungsgeschichte Der Preubischen Staatsbibliothek, Berlin 2003, s. 16. 
rękopisów, ale w I943 r. władze centralne podjęły decyzję, że rezydencja książąt Hochberg von Pless będzie zajęta na potrzeby Kancelarii Rzeszy. Z powodu podjętych prac budowlanych, w lutym 1944 r. gauleiter Dolnego Śląska, Karl Hanke, zlecił inwentaryzacje przechowywanych $w$ zamku dóbr kultury i rozstrzygnięcie, które z nich będa mogły pozostać, a które zostana wywiezione ${ }^{9}$. Ostatecznie zdecydowano o przeniesieniu zabytkowego wyposażenia zamku oraz depozytów umieszczonych w książęcej rezydencji do innych lokalizacji. Do wywiezienia przeznaczono m.in. kolekcję modeli zamków i kościołów, zbiory entomologiczne, zabytkowa broń, pieczęcie, miniatury, instrumenty muzyczne oraz depozyt Pruskiej Biblioteki Państwowej ${ }^{\text {io }}$. Skrzynie zawierające cenne rękopisy przeniesiono do opactwa benedyktynów w Krzeszowie. 2I lutego I944 r. prof. Grundmann poinformował biuro budowy na zamku Książ, że zlecił przewiezienie 400 skrzyń [Werner Schochow w swojej książce Bucherschicksale: Die Verlagerungsgeschichte Der Preubischen Staatsbibliothek podaje, że skrzyń było 505] z zasobami Pruskiej Biblioteki Państwowej do kościoła św. Józefa w Krzeszowie ${ }^{\text {II }}$.

Dyrekcja berlińskiej Biblioteki nie była zadowolona $\mathrm{z}$ decyzji przeniesienia jej zbiorów do Krzeszowa. Prof. Grundmann tłumaczył jednak, że ze względu na prace budowlane zagrażające bezpieczeństwu manuskryptów musiał podjąć tego typu działania. Na początku marca 1944 r. konserwator otrzymał kolejny list w tej sprawie. Pańska wiadomość dotyczaca wywiezienia naszych zasobów z Ksiaża nie była dla nas miła, ale nie ma innego wyjścia. Jesteśmy panu wdzięczni za wyznaczenie odpowiedniej składnicy i troskliwy nadzór nad przenosinami $^{\text {I2}}$. Wskutek podjętych decyzji i akceptacji tego rozwiązania przez berlińskich bibliotekarzy w lipcu 1944 r. w Krzeszowie znalazł się najbardziej pokaźny zasób Pruskiej Biblioteki Państwowej na wschodzie ${ }^{13}$. Depozyt bezpiecznie przetrwał wojnę i był jednym z pierwszych, które zabezpieczyła polska komisja rewindykacyjna działająca na Dolnym Śląsku pod kierownictwem prof. Stanisława Lorentza - pełniącego funkcję dyrektora Muzeum Narodowego w Warszawie i Naczelnego Dyrektora Muzeów i Ochrony Zabytków. Rezultatem podjętych przez nią działań było m.in. odnalezienie licznych składów książek (m.in. w Krzeszowie) itd. ${ }^{I 4}$. Zbiory Pruskiej Biblioteki Państwowej odnalezione w tej lokalizacji pozostawiono na miejscu do I946 r. Dopiero wtedy rozpoczęto przenoszenie kolekcji do Krakowa. Ostatecznie do gmachu Biblioteki Jagiellońskiej - pełniącego też funkcję lokalnej Zbiornicy Księgozbiorów Zabezpieczonych - przetransportowano 490 skrzyń ${ }^{15}$. Badania

\footnotetext{
9 Protokół oględzin zamku Książ z 8 II 1944 r., Marburg, Herder-Institut für historische Ostmitteleuropaforschung, Institut der Leibnitz-Gemeinschaft, Dokumentesammlung, Zespół Günthera Grundmanna (dalej: Marburg, Herder-Institut, Dok. Z. G.G.), dok. 1/203.

10 J.M. Kowalski, J.R. Kudelski, R.Sulik, Lista Grundmanna. Tajemnice skarbów Dolnego Śląska, Warszawa 2015, s. 155.

11 Pismo prof. Günthera Grundmanna do biura budowy na zamku Książ z 21 II1944 r., Marburg, Herder-Institut, Dok. Z. G.G., dok. 1/204.

12 Pismo dyrekcji Pruskiej Biblioteki Państwowej do prof. Günthera Grundmanna z 2 III 1944 r., Marburg, Herder-Institut, Dok. Z. G.G., dok. 1/206.

13 W. Schochow, Bücherschicksale: Die Verlagerungsgeschichte Der Preubischen Staatsbibliothek, Berlin 2003, s. 7 .

14 W. Kieszkowski, Składnica muzealna Paulinum, w: Pamiętnik Związku Historyków Sztuki i Kultury, Warszawa 1948, tom 1, s. 141.

15 P. Lechowski, Sporna Berlinka. Kontrowersje wokół zbiorów byłej Pruskiej Biblioteki Państwowej przechowywanych w Bibliotece Jagiellońskiej w Krakowie, „Biuletyn EBIB”, nr 8/2008 (99), http://www.ebib.pl/2008/99/a. php?lechowski [dostęp z 16.06.2016].
} 
tych zasobów wykazały, że znajduje się w nich około 500 tys. archiwaliów - m.in. rękopisy, modlitewniki, autografy muzyczne oraz listy wybitnych postaci niemieckiej kultury i nauki.

Latem 1942 r. dolnośląski konserwator zabytków - działając w imieniu dyrekcji Pruskiej Biblioteki Państwowej - kontynuował poszukiwania miejsc, w których byłaby możliwość zdeponowania kolejnych partii zbiorów berlińskiej instytucji. Jedną z lokalizacji, którą brano pod uwagę był pałac rodziny Hochbergów w Rohnstock (Roztoce) w powiecie świdnickim. Po wielu miesiącach rozmów z właścicielem tego majątku - hrabią Hansem Heinrichem XVIII von Hochbergiem - prof. Grundmann otrzymał zgodę na umieszczenie w rostockim pałacu skrzyń z berlińskimi zbiorami. Dyrekcja Pruskiej Biblioteki Państwowej przystąpiła do przygotowana transportu. Prof. Grundmann niezwłocznie poinformował o podjętych działaniach hrabiego von Hochberga. By móc wykonywać niezbędne prace bibliotekarskie potrzeba jest oprócz pomieszczeń do składowania książek, które nie musza być ogrzewane, 2-3 oddzielnych ogrzewanych pokoi mieszkalnych dla pracowników tej instytucji ${ }^{16}$. Kolejnym krokiem miała być inspekcja pomieszczeń pałacu w Roztoce przeznaczonych na składnicę. Do wykonania tego zadania oddelegowano członka kierownictwa Pruskiej Biblioteki Państwowej, Josefa Beckera - w latach dwudziestych XX w. dyrektora wrocławskiej Universitätsbibliothek (Biblioteka Uniwersytecka) i Stadtbibliothek (Biblioteka Miejska). Do wizyty Beckera jednak nie doszło, a plany przeniesienia zbiorów berlińskiej instytucji do pałacu w Roztoce zostały odłożone. Powodem była decyzja dowództwa niemieckiej armii, które zamierzało wykorzystać wolne pomieszczenia w rezydencji hrabiego von Hochberga na potrzeby wojenne. Prof. Grundmann miał nadzieję, że jest to sytuacja przejściowa. Dlatego w liście do właściciela majątku w Roztoce pisał: Zakładając, że dojdzie do porozumienia $z$ Wehrmachtem, należy wszystkie inne propozycje wykorzystania pałacu odrzucać, dając priorytet interesom Staatsbibliothek zu Berlin ${ }^{17}$. W grudniu 1942 r. von Hochberg odpowiedział konserwatorowi, że dowództwo wojskowe nie zamierza rezygnować z wykorzystania zajętych pomieszczeń pałacu. Z tego té̇ powodu nie jest dla mnie możliwym by oddać do dyspozycji pomieszczenia niezbędne dla zabezpieczenia zbiorów bibliotecznych. Dla ustawienia skrzyń z książkami mógtbym jednak zwolnić dwa duże pokoje, ale wtedy nie miałbym już żadnych innych wolnych pomieszczeń, gdyż pozostałe zarekwirowat Wehrmacht lub też zostały zastawione zgromadzonymi tam meblami i obrazami ${ }^{18}$.

Do rozmów na temat możliwości wykorzystania pałacu w Roztoce na składnicę zasobów Pruskiej Biblioteki Państwowej powrócono w lipcu I943 r. Do tego czasu prof. Grundmann wykorzystał już jednak część wolnych pomieszczeń na zdeponowanie w nich zbiorów wrocławskiego Schlesische Museum der Bildenden Künste (Śląskiego Muzeum Sztuk Pięknych). Dlatego o planach umieszczenia w Roztoce manuskryptów z Berlina poinformował komisarza Śląskiego Muzeum Sztuk Pięknych, dr. Hubertusa Lossowa: Planuję wykorzystać pozostałe wolne pomieszczenia w pałacu [w Roztoce] w celu zabezpieczenia w nich cennych zbiorów Pruskiej Biblioteki Państwowej ${ }^{19}$. Mimo zaawansowanych przygotowań do ewakuacji zbiorów

\footnotetext{
16 Pismo prof. Günthera Grundmanna do hrabiego Hansa Heinricha XVIII von Hochberga z 2 XII 1942 r., Marburg, Herder-Institut, Dok. Z. G.G., dok. 2/290.

17 Tamże.

18 Pismo hrabiego Hansa Heinricha XVIII von Hochberga do prof. Günthera Grundmanna z 4 XII 1942 r., Marburg, Herder-Institut, Dok. Z. G.G., dok. 2/291.

19 Pismo dr. Hubertusa Lossowa do hrabiego Hansa Heinricha XVIII von Hochberga z 14 VII 1943 r., Marburg, Herder-Institut, Dok. Z. G.G., dok. 2/307.
} 
berlińskich prof. Grundmann musiał wstrzymać tę operację. Powodem zmiany planów był list, jaki otrzymał od hrabiego von Hochberga I5 lipca 1943 r. Właściciel pałacu informował w nim konserwatora, że podejmowane sa działania by zakwaterować [w rezydencji] osoby $z$ zagrożonych bombardowaniami miast ${ }^{20}$. Z powodu niepewności dotyczącej sposobu wykorzystania pałacu w Roztoce prof. Grundmann zrezygnował z planów umieszczenia w tym miejscu zasobów Pruskiej Biblioteki Państwowej.

W pierwszej połowie 1942 r. dyrekcja Pruskiej Biblioteki Państwowej planowała ewakuować z Berlina koleją partię swoich zbiorów. Cenne manuskrypty planowano umieścić w średniowiecznym zamku w miejscowości Gröditzberg (Grodziec w powiecie złotoryjskim). Inspekcję pomieszczeń przeznaczonych na składnicę biblioteczną przeprowadzili Josef Becker i Wilhelm Poewe. Obaj uznali tę lokalizację za właściwą dla zabezpieczenia dóbr biblioteki i niedtugo później otrzymali zgodę właściciela zamku von Dirksena [niemieckiego dyplomaty Herberta von Dirksena] na umieszczenie w nim zbiorów ${ }^{21}$. Manuskrypty miały być złożone w Sali Rycerskiej na wysokim parterze zamku. Posiadała ona powierzchnię o wymiarach 8xI2 metrów i mogła mieścić - wedlug raportu Poewe - 250 skrzyńn ${ }^{22}$. Warto wspomnieć, że właśnie w tej części zamku rodzina Dirksenów zgromadziła również własne zbiory sztuki. W Sali Rycerskiej przechowywano m.in.: dwie zbroje rycerskie z I pot. $X V w$., renesansowe szafy ze zdobieniami, hakownice z II pot. XV w., broń landknechta $z X V$ w. inne średniowieczne uzbrojenie, trąbki z I686 r. wykonane w zakładzie J.K. Radischa $w$ Norymberdze, fragment pięknej perskiej zbroi, model maszyny oblężniczej z XVIw., hiszpański róg do picia z XIV w., modele broni z XVI w., i broń myśliwska z XV i XVI w. Liczne obrazy przedstawiaty kolejnych władców Niemiec poczawszy od Fryderyka Wilekiego aż do Fryderyka Wilhelma IV, Teodora Körnera, Ludwika XIV, generała Seidlitza, cesarza Józefa I, generała Ziethena, Gustava Adolfa, Wallensteina i Tilly'ego ${ }^{23}$. Inne części zamku były również wypełnione zbiorami sztuki i zabytkami archeologicznymi. Do takich „wolnych” - pomieszczeń pod koniec września 1942 r. przywieziono skrzynie z berlińskimi manuskryptami. Osobami odpowiedzialnymi za ewakuację i ochronę tych zasobów byli Johannes Brede i Walter Schwarzenecker. Dzięki ich sprawozdaniu z operacji wiemy, że do Grodźca przywieziono 250 skrzyń. Po dotarciu pociągu na stację kolejową - oddaloną o około trzy kilometry od zamku - depozyt załadowano na samochody ciężarowe. Wcześniej jednak konieczny byt postój u stóp wewnętrznej bramy zamku, ponieważ drewniany most zwodzony nad fosą nie miat wystarczającej nośności by móc udźwignąć wszystkie trzy samochody ciężarowe. Tak więc przy pomocy zaprzęu konnego przewieziono skrzynie na druga strone mostu. Pracownicy firmy spedycyjnej Hohberg z miejscowości Goldberg [Złotoryja] dalej znosili zbiory do dolnej sali zamkowej (rycerskiej) i układali je wzdtuż dtuższych ścian, w podwójnych rzędach, po trzy jedne na drugich ${ }^{24}$. Skrzynie złożone w zamku zawierały m.in. ponad 5 tys. wczesnych druków Marcina Lutra, ponad 6 tys. manuskryptów, listów i dokumentów pisarza Gottholda Ephraima Lessinga (przekazanych Bibliotece przez Carla

\footnotetext{
20 Pismo hrabiego Hansa Heinricha XVIII von Hochberga do prof. Günthera Grundmanna z 15 VII 1943 r., Marburg, Herder-Institut, Dok. Z. G.G., dok. 2/309.

21 W. Schochow, Bücherschicksale..., s. 74.

22 Tamże.

23 M. Olczak, Grodziec. Przewodnik historyczny, Warszawa 2000, s. 42-43.

24 W. Schochow, Bücherschicksale..., s. 74-75.
} 
Roberta Lessinga), ponad 3 tys. inkunabułów, około I4 tys. tomów dzieł z działu muzycznego, liczącą ponad tysiąc dokumentów spuściznę po niemieckim kompozytorze Giacomo Meyerbeerze oraz około 4 tys. tomów dzienników wschodnioniemieckich.

Rok po przeprowadzeniu operacji zdeponowania zbiorów Pruskiej Biblioteki Państwowej w zamku w Grodźcu ponownie rozważano możliwość wykorzystania tej lokalizacji jako miejsca ewakuacji zasobów berlińskiej instytucji. We wrześniu i943 r. Herbert von Dirksen dowiedział się, że dyrekcja Pruskiej Biblioteki Państwowej rozważa wybudowanie w pobliżu zamku baraków, mających stanowić magazyny zasobów tej instytucji. Baraki będa zbudowane w konstrukcji fachwerkowej [tzw. mur pruski] ze ścianami obłożonymi pumeksem. Każdy z nich będzie miał 38 m długości, 9 m szerokości i 3 m wysokości, wdwóch przypadkach przewiduje się baraki o dtugości $19 \mathrm{~m}^{25}$. O planach berlińskich bibliotekarzy von Dirksen poinformował dolnośląskiego konserwatora zabytków. Prof. Grundmann zalecił właścicielowi majątku zachowanie rozwagi w podejmowaniu decyzji o udostępnieniu gruntu pod tego typu inwestycję. Twierdził m.in., że realizacja takiego zamierzenia $w$ znacznym stopniu wptynie na ukształtowanie krajobrazu i z tego powodu lokalizacja baraku powinna być wybrana nadzwyczaj starannie ${ }^{26}$. Przy okazji wymiany tej korespondencji konserwator zapytał von Dirksena, czy w zamku znajdują się wolne pomieszczenia, które można by było wykorzystać na potrzeby składnicy zbiorów sztuki. Właściciel rezydencji opisał szczegółowo przestrzeń jaką dysponował. Główny budynek zamku, Pallas, liczy tylko dwa piętra. Poza tym jest duża, bardzo wilgotna piwnica i strych pod wysokim, strzelistym dachem. Moim zdaniem ani piwnica, ani poddasze nie wchodza $w$ rachubę $e^{27}$. W pozostałej części zamku wiele pomieszczeń było już wypełnionych zbiorami różnych instytucji - m.in. Mineralogisch-Petrographisches Institut (Instytut Mineralogiczno-Petrograficzny Uniwersytetu Wrocławskiego), Stadtarchiv der Stadt Breslau (Archiwum Miejskie Wrocławia). Wkrótce do Grodźca - do pałacu pełniącego funkcję rezydencji von Dirksena - zaczęto przywozić kolejne zasoby archiwalne różnych niemieckich instytucji (w tym Ministerstwa Spraw Zagranicznych z Berlina i Osteuropa-Institut z Wrocławia). Nie zachowały się dokumenty, które wskazywałyby na wykorzystanie kolejnych przestrzeni zamku i pałacu w Grodźcu przez Pruską Bibliotekę Państwową. Z powojennych relacji wiemy, że $w$ Grodzisku [Grodzisko, Grodziszcze - powojenne nazwy Grodźca] niedaleko Złotoryi, na przełomie lutego i marca 1945 roku, spłonęło $w$ zamku około 250 skrzyń Preussische Staatsbibliothek $w$ Berlinie. Rosjanie wywieźli z tej miejscowości bibliotekę Osteuropa-Institut [zdeponowaną w pałacu, a nie zamku], przywieziona przez Niemców z Wrocławia. Na miejscu pozostały katalogi alfabetyczny $i$ systematyczny ${ }^{28}$. Informację o zniszczeniu części zasobu Pruskiej Biblioteki Państwowej zdeponowanego w Grodźcu potwierdzają również niemieccy historycy i bibliotekarze. Chwile po tym jak miejscowość [Grodziec] bez walki zajęli Rosjanie (I5/I6 lutego I945 r.), od I8 lutego do 03 marca I945 zamek, a w szczególności Pallas łącznie ze skarbami

25 Pismo barona Herberta von Dirksena do prof. Günthera Grundmanna z 19 IX 1943 r., Marburg, Herder-Institut, Dok. Z. G.G., dok. 1/241.

26 Pismo prof. Günthera Grundmanna do barona Herberta von Dirksena z 27 IX 1943 roku, Marburg, Herder-Institut, Dok. Z. G.G., dok. 1/242.

27 Pismo barona Herberta von Dirksena do prof. Günthera Grundmanna z 1 X 1943 roku, Marburg, Herder-Institut, Dok. Z. G.G., dok. 1/243.

28 R. Nowicki, Zabezpieczanie księgozbiorów po II wojnie światowej w Polsce, „, Napis. Pismo poświęcone literaturze okolicznościowej i użytkowej”, Seria XI, 2005, s. 283. 
biblioteki berlińskiej, spłonęły doszczętnie. Najbardziej dotkliwą strata były niezastapione i cenne zbiory inkunabułów $w^{29}$. W niemieckich opracowaniach dotyczących losów tej składnicy znajduje się również inna informacja potwierdzająca los kolekcji Pruskiej Biblioteki Państwowej przywiezionej do tej miejscowości. Wedtug relacji naocznych świadków jesienia 1945 r. mieli oni widzieć szara, gruba na ponad Io/I5 cm warstwę popiołu wapiennego. Zwęglony lub do połowy spalony papier, pozostawiajacy widoczne ślady grzbietów książek rozpadat się przy najmniejszym dotknięciu ${ }^{30}$. Polskie komisje rewindykacyjne, które dotarły do Grodźca po opuszczeniu zamku przez oddziały radzieckie (stacjonujące tam jeszcze wiele miesięcy), odnalazły tylko fragment prywatnych zbiorów von Dirksena. Nie było tam jednak depozytów bibliotecznych przywiezionych z Berlina. We wspomnieniach Witolda Kieszkowskiego, nadzorującego - z ramienia Naczelnej Dyrekcji Muzeów i Ochrony Zabytków - rewindykację dóbr kultury na Dolnym Śląsku, znajduje się informacja na temat warunków, w jakich prowadzono zabezpieczenie zbiorów odnalezionych w Grodźcu. Niedawno wspominaliśmy z kolegami, jak to o pólnocy przy świetle reflektorów, zapalniczek i zapałek gdyż baterie do lampek elektrycznych zostały wyczerpane, tadowaliśmy zbiory na zamku i w pałacu $w$ Grodzisku, aby tylko nie zmarnować czasu i nie dopuścić, aby samochody wracały puste do domu ${ }^{\text {II }}$. Kieszkowski także nie wspomina o odnalezieniu jakichkolwiek zbiorów, które mogłyby należeć do zasobów Pruskiej Biblioteki Państwowej.

Latem 1943 r. na Dolnym Śląsku powstała kolejna składnica, w której umieszczono zbiory Pruskiej Biblioteki Państwowej. Pierwotnie planowano, że na potrzeby tej instytucji zostaną wykorzystane wolne pomieszczenia zamku w Gościszowie (powiat bolesławiecki), którego właścicielami byli Friedrich Karl i Hildegarda von Eggeling. Jednak ze względu na wartość historyczną tego obiektu, dolnośląski konserwator zabytków podjął decyzję, by zasoby biblioteczne umieścić w innej składnicy. Ponieważ w tej samej miejscowości znajdowały się obiekty kościelne, prof. Grundmann zwrócił się do Evangelisches Konsistorium der Kirchenprovinz Schlesien (Konsystorium Ewangelickie Śląskiej Prowincji Kościelnej) we Wrocławiu z prośbą o udostępnienie pomieszczeń kościelnych w Gościszowie na przechowanie w nich dóbr kultury. Urząd konsystorza skonsultował tę sprawę z lokalną radą kościelną. Odpowiedź w tej sprawie nadeszła Io października I943 r. Rada Gminy Ewangelickiej, po szczegółowej dyskusji postanowiła jednomyślnie, będąc posłuszna patriotycznemu obowiązowi-oddać do dyspozycji zbór ewangelicki jako miejsce usytuowania zabytków na czas wojny, pod warunkiem, że po jej zakończeniu zbór zostanie zwrócony dla posługi kościelnej, a wszelkie powstałe szkody finansowe będą kościołowi zrekompensowane ${ }^{32}$. Otrzymawszy tę odpowiedź, konserwator zorganizował inspekcję pomieszczeń, które miały stać się magazynem dla manuskryptów ewakuowanych z Berlina. Ze spotkania w tej sprawie - w którym wzięli udział proboszcz Hellmuth Klein i dr Kurt Sommer z urzędu konserwatorskiego - sporządzono notatkę, z której wynika, że zbór mógł udostępnić 5II metrów bieżacych wolnej przestrzeni. O efektach przeprowadzonej inspekcji poinformowano również dyrektora Pruskiej Biblioteki Państwowej Hugo Andresa Krüssa: Dr Sommer doliczył się 600 metrów bieżacych na

29 W. Schochow, Bücherschicksale..., s. 76.

30 Tamże, s. 77.

31 W. Kieszkowski, Składnica muzealna Paulinum..., s. 153.

32 Protokół posiedzenia rady gminy ewangelickiej w Gościszowie z 10 X 1943 r., Marburg, Herder-Institut, Dok. Z. G.G., dok. 1/218c. 
zmagazynowanie książek. Sądzę, że wyliczenie to nie jest $w$ petni miarodajne, ponieważ książek nie trzeba układać na stojąco, można je ułożyć warstwami. W każdym razie jestem przekonany, że pojemność rozsądnie wypetnionego zboru w Gościszowie praktycznie odpowiada pojemności specjalnego baraku na książki33. Prof. Grundmann poinformował również berlińskich bibliotekarzy o stanie technicznym pomieszczeń wybranych na składnicę. Stalle sa w bardzo dobrym stanie, niezwykle wytrzymałe, na tyle, by można tu było układać książki do wysokości ławki, później ułożyć deski nad oparciami i na nowo ustawiać na nich książki tworzac stos. Emporia kościelne podobnie mają dość duży udźwig. W każdym razie jestem przekonany, iż zbór w Gościszowie z praktycznego punktu widzenia jest idealnym miejscem dla przechowania ksiażek ${ }^{34}$. W listopadzie 1943 r. dyrektor Pruskiej Biblioteki Państwowej wyraził zgodę na umieszczenie w Gościszowie zbiorów berlińskiej placówki.

Transport zasobów bibliotecznych z Berlina do Gościszowa zaplanowano na styczeń I944 r. Wysyłka książek odbyła się drogą kolejową w dwóch etapach (styczeń 1944). W pierwszym etapie od 3I grudnia I943 r. do o6 stycznia I944 r. odprawionych zostało sześć wagonów zawierających różne książki, $w$ drugim etapie, po niedtugiej przerwie, tzn. od I9 do 30 stycznia kolejne dwanaście wagonów (I80 ooo kg). Książki dojeżdżały koleja do Bunzlau [Bolesławiec], nastepnie samochody transportowe miejscowej firmy przejmowały ładunek, również tamtejsza ludność wiejska była czynnie zaangażowana $w$ akcję ewakuacyjna ${ }^{35}$. Johannes Brede, który został wyznaczony do opieki nad zbiorami umieszczonymi w gościszowskim kościele pisał później, że książki ustawione byty w trzech blokach o wysokości 2-2,5 m. Kościelny - Paul Wieland-zabezpieczył okna przed stońcem oraz uchronił depozyt przed możliwościa dostrzeżenia jego zawartości z zewnątrz ${ }^{36}$. Współpracownik Bredego Kurt Tautz - uzupełnił przytoczoną relację w następujący sposób: Chyba nawet bardziej niż w Karpnikach odnosiło się tu - w tym niezwykle wysokim pomieszczeniu - przygnębiajace wrażenie użycia książki niczym kamienia budowlanego, można było wygodnie wędrować pomiędzy książkowymi budowlami, poruszajac się po rozległych uliczkach, utworzonych z masywnych, wysokich, nie posiadajacych najmniejszej szczeliny, murach z ksiązek ${ }^{37}$. Inwentaryzacja zbiorów przewiezionych do Gościszowa wykazała, że w lokalnym kościele zdeponowano 280 tys. tomów starodruków oraz I4 skrzyń zawierających prywatne zbiory Hugo Andresa Krüssa. Najprawdopodobniej pod koniec I944 r. w kościele umieszczono również skrzynie ze zbiorami Śląskiego Muzeum Sztuk Pięknych we Wrocławiu. Na początku stycznia 1945 r. część tej kolekcji została przeniesiona do miejscowości Roßla am Harz. Większość starodruków Pruskiej Biblioteki Państwowej zdeponowanych w Gościszowie spłonęła kilka tygodni później w czasie działań wojennych. Informacje na temat przebiegu tego wydarzenia miał przekazać berlińskim bibliotekarzom gościszowski pastor Hellmuth Klein. Z powodu braku jakichkolwiek możliwości ugaszenia pożaru, zbór ewangelicki wraz $z$ drewniana konstrukcją dachu spłoną doszczętnie. Jeszcze pod koniec maja I945 r. pośród zgliszczy można było rozpoznać zwęglone grzbiety książek biblioteki berlińskiej. Ślady

33 Pismo prof. Günthera Grundmanna do Hugo Andresa Krüssa z 2 XI 1943 r., Marburg, Herder-Institut, Dok. Z. G.G., dok. 1/222.

34 W. Schochow, Bücherschicksale..., s. 143.

35 Tamże, s. 144.

36 Tamże.

37 Tamże. 
popiołu, puste okna zboru, widoczne znaki strawionych pożarem pomieszczeń przez kolejne dziesiatki lat pozostały bez zmian ${ }^{3}$.

Ostatnia faza ewakuacji zasobów Pruskiej Biblioteki Państwowej na Dolny Śląsk miała miejsce w I944 r. Z uwagi na katastrofalną sytuację, w jakiej znalazły się niemieckie miasta - będące celem nawet dziennych nalotów dywanowych - dyrekcja tej instytucji podjęła starania zmierzające do przeniesienia dalszych partii swoich zasobów na bezpieczną prowincję. W porozumieniu z władzami dolnośląskimi ustalono, że kolejny depozyt berlińskiej biblioteki zostanie umieszczony w zamku Fischbach (Karpniki w powiecie jeleniogórskim), którego właścicielem był książę Ludwig von Hessen. Rezydencja już wcześniej stała się miejscem zdeponowania zbiorów sztuki - prywatnej kolekcji rodziny książęcej oraz zasobów przywiezionych z Großherzoglichen Museums (Muzeum Wielkich Książąt Heskich) w Darmstadt. W lutym I944 r. zarządca karpnickiego majątku, Eduard Neuschäffer, został poinformowany przez starostę powiatu jeleniogórskiego, iż na podstawie „£ 25 Reichsleistungsgesetz [Ustawa o Świadczeniach na rzecz państwa] z I.9.1939 RGB [Reichsgesetzblatt, dziennik ustaw Rzeszy] I, s. I645" kilka pomieszczeń zamku ma zostać zajętych na potrzeby przechowania w nich Reichspressearchiv (Archiwum Prasowego Rzeszy) i zbiorów Pruskiej Biblioteki Państwowej39. Nadzór nad przewiezieniem do Karpnik zasobów bibliotecznych powierzono Hansowi Jessenowi - członkowi rady Pruskiej Biblioteki Państwowej. Transport miał dostarczyć na miejsce około 20 tys. tomów niemieckiej prasy (dzienników). Mimo decyzji podjętych przez władze starostwa zarządcy książęcego majątku nie chcieli brać na siebie odpowiedzialności za opiekę nad berlińskimi zbiorami. Okazało się również, że sprawa ewakuacji do Karpnik zasobów Pruskiej Biblioteki Państwowej i Archiwum Prasowego Rzeszy nie była uzgodniona z dolnośląskim konserwatorem zabytków. W tej sytuacji zarządca dóbr książęcych poinformował starostę jeleniogórskiego, iż na podstawie decyzji konserwatora zabytków pana prof. dr. Grundmanna i zgodnie z przepisami Reichsleistungsgesetz pałac w Karpnikach już petni określona funkcję, w związku z czym jakiekolwiek zmiany w jego użytkowaniu nie moga być wprowadzane bez uzgodnienia z Komisarzem Obrony Rzeszy [Reichsverteidigungskommissar ${ }^{40}$. Ponieważ obawiano się skutków konfliktu, jaki mógł wyniknąć z zaistniałej sytuacji, zarządca majątku (w porozumieniu z prof. Grundmannem) postanowił udostępnić zasobom ewakuowanym z Berlina jedno z wolnych pomieszczeń w zamku i oddać do dyspozycji tzw. Dom Ogrodnika. Na umieszczenie w rezydencji książęcej większej ilości skrzyń nie pozwalała nośność stropów. Z analiz przeprowadzonych przez eksperta wynikało, że zgodnie z normami budowlanymi: I) przy składowaniu regałów i szaf z zawartościa (także niepetna) w postaci akt, książek, archiwów itd. przewidziane jest obciażenie o wadze o,6 tony na metr. 2) Przy składowaniu papieru (czasopism) przewidziane jest obciażenie o wadze I,I tony na metr ${ }^{4}$. Mimo to prof. Grundmann starał się pomóc bibliotekarzom z Berlina w znalezieniu wolnych pomieszczeń dla zbiorów przygotowanych do ewakuacji. W celu znalezienia satysfakcjonującego rozwiązania do Karpnik przyjechał Josef Becker. Dyrektor Becker byt w Karpnikach i poinformowat mnie, że między nim

\footnotetext{
38 Tamże, s. 145.

39 Pismo starosty powiatu jeleniogórskiego do nadleśniczego Eduarda Neuschäffera z 25 II 1944 r., Marburg, Herder-Institut, Dok. Z. G.G., dok. 1/166.

40 Pismo przedstawiciela zarządu majątków Wielkiego Księcia Hesji do starosty powiatu jeleniogórskiego z 9 III 1944 r., Marburg, Herder-Institut, Dok. Z. G.G., dok. 1/165.

41 Ekspertyza specjalisty budowlanego Klose z 10 III 1944 r., Marburg, Herder-Institut, Dok. Z. G.G., dok. 1/169.
} 
i nadleśniczym Neuschäffem doszło do porozumienia uwzględniającego potrzeby Biblioteki Państwowej i Großherzogliche Vermögensverwaltung [Zarządu Majątku Wielkich Książąt Heskich $]^{42}$. Dzięki tym ustaleniom berliński depozyt przywieziono koleją do Jeleniej Góry, a stamtąd do Lomnitz (Łomnica) niedaleko Karpnik. Na dworcu skrzynie przepakowano na samochody ciężarowe i przewieziono do zamku. Wokresie od I3 maja do 25 września $1944 r$. do zamku w Karpnikach trafiło łącznie 6000 cetnarów [300 $000 \mathrm{~kg}$ ] gazet przewiezionych w 2 I wagonach. Wedtug dokumentów było to ok. 20 ooo tomów lub tzw. plików. Rozdzielone zostaty pomiędzy trzy części budowli i pod kierownictwem Eugena Paunela, tam gdzie byto to możliwe (niekiedy na wysokość kilku metrów), poustawiane przy ścianach $-w$ zamku (cztery pomieszczenia na parterze oraz pierwszym piętrze, tylko częściowo nadawaty sie do użytku), w budynku gospodarczym (sześć pomieszczeń) oraz w wolnostojącej szopie [tzw. Domu Ogrodnika] w parku przyzamkowym ${ }^{43}$. O powojennych losach tych zasobów wiemy niewiele. W lutym 1945 r. do Karpnik przyjechał prof. Grundmann, któremu udało się wywieźć z zamku część książęcej kolekcji obrazów. Po nim do majątku dotarł przedstawiciel Kunstschutzu - komórki niemieckiego sztabu generalnego odpowiedzialnej za zabezpieczanie dzieł sztuki na terenach okupowanych - hrabia Ernst Otto Solms-Laubach, który zabrat resztę przedmiotów, przywiezionych z Darmstadtu oraz szereg obrazów i pamiatek, które stanowiły wyposażenie zamku ${ }^{44}$. Kilkadziesiąt tysięcy tomów gazet i dokumentów pozostawiono na miejscu - brakowało czasu i środków transportowych, by wywieźć je w bezpieczne miejsce. Po wojnie nieustalona część zasobów Pruskiej Biblioteki Państwowej odnalezionych w Karpnikach została przewieziona do Krakowa45. Zbiór zdeponowano w kilku placówkach, później zaś - o ile nie zostały oddane na makulaturę - trafity częściowo do instytutów w Olsztynie i Łodzi. Pokaźna część dzienników [niemieckiej prasy] z Karpnik trafita w 1965 r. z powrotem do Berlina ${ }^{46}$.

Ostatnim akordem ewakuacji zbiorów Pruskiej Biblioteki Państwowej na Dolny Śląsk była decyzja o przetransportowaniu z Berlina do Hirschbergu (Jeleniej Góry) działu katalogów tej instytucji ${ }^{47}$. Działania zmierzające do realizacji tego planu podjęto na wiosnę $1944 \mathrm{r}$. Zasoby tej komórki wraz z jej pracownikami zostały ulokowane w Museum des Riesengebirgsvereins (od 1938 r. Sudetenmuseum, dziś Muzeum Karkonoskie) oraz Archiwum Miejskim (do niedawna mieściło się tam Archiwum Państwowe) $)^{48}$. Położone u podnóża gór małe miasteczko udzieliło schronienia w pomieszczeniach Archiwum Miejskiego i Muzeum Karkonoskiego przede wszystkim częściom działu gromadzenia oraz działu katalogów, w tym dużej części wielotomowego katalogu rzeczowego. Wostatnich latach wojny biblioteka prowadzona była troskliwie przez Rudolfa Juchhoffa i Eugena Paunela. Działający w Jeleniej Górze dziat byt personalnie najsilniejszym zewnętrznym oddziałem Pruskiej Biblioteki Państwowej49.

\footnotetext{
42 Pismo prof. Günthera Grundmanna do przedstawicieli zarządu majątków Wielkiego Księcia Hesji z 30 III 1944 r., Marburg, Herder-Institut, Dok. Z. G.G., dok. 1/170.

43 W. Schochow, Bücherschicksale..., s. 151.

44 W. Kieszkowski, Sktadnica muzealna Paulinum..., s. 147-148.

45 J.R. Kudelski, Zbiory sztuki na zamku w Karpnikach w czasie II wojny światowej, mps.

46 W. Schochow, Bücherschicksale..., s. 151-152.

47 K. Trautz, Die Preussische Staatsbibliothek in Hirschberg im Riesengebirge zur zeit des zweiten grossen krieges, 1944-1945, Berlin 1950.

48 W. Schochow, Die Dienststelle Hirschberg (1944-1945), Berlin 1994.

49 W. Schochow, Bücherschicksale..., s. 147.
} 
Sprawność funkcjonowania tej komórki zapewniono dzięki sprowadzeniu na Dolny Śląsk jedenastu bibliotekarzy dziedzinowych oraz pięciu dyplomowanych bibliotekarek katalogu rzeczowego; ponadto dziatu sporzadzajacego wydruki sygnatur. Przy petnej obsadzie jednostka liczyła nawet od 46 do 49 pracowników. Poza dokumentacja umów adhezyjnych ważnym instrumentem pracy w jednostce byt katalog rzeczowy, którego tomy od kwietnia I944 $r$. dostępne byty w budynku archiwum, a on sam byt uzupetniany dalej o nowe nabytki $i^{\circ}$. W ramach operacji przeprowadzonej wiosną 1944 r. do Jeleniej Góry przewieziono 6000 pozycji z oddziału prowadzacego opracowywanie książek oraz części biblioteczki podręcznej katalogu rzeczowego i dziatu kartoteki; 1926 tomów katalogu realnego (poza naukami przyrodniczymi, technika) $)^{51}$. Do gmachu Muzeum Karkonoskiego przywieziono zaś 17 ooo pozycji z oddziatu zajmującego się opracowaniem książek (nowe dostawy); I5o paczek zawierających akta oraz dział gromadzenia zbiorów i dziat katalogowy ${ }^{52}$.

W czerwcu 1944 r. placówkę w Jeleniej Górze odwiedził dyrektor Pruskiej Biblioteki Państwowej Hugo Andres Krüss. Po dokonaniu inspekcji uznał on, że zarówno personel, jak i ewakuowane zasoby mogą bezpiecznie czekać tu na zakończenie wojny. Postępy wojsk radzieckich oraz ofensywa styczniowa - której celem było m.in. zajęcie Dolnego Śląska i marsz na Berlin - spowodowały, że Krüss musiał postanowić sprowadzić wydział katalogów z powrotem do Berlina. Reewakuacja udała się tylko częściowo. Część akt i tomów zostało zabranych z powrotem do Berlina (początek kwietnia), w przeciwnym razie musiałyby zostać na miejscu i być tam zabezpieczone. Większość pracowników - w terminie od Io do 27 lutego (inni dopiero na początku kwietnia) - została zwolnion ${ }^{53}$. W chaosie ostatnich tygodni wojny okazało się jednak, że do Jeleniej Góry wysłano jeszcze transport zawierający zasoby działu opraw i kartoteki, nadanych w Berlinie między styczniem, a początkiem kwietnia $1945 r^{54}$ I kwietnia z Jeleniej Góry do Berlina wyjechał transport zawierający księgi rachunkowe, akta oraz I0oO pozycji z biblioteczki podręcznej. Na miejscu pozostawiono jednak dużą część zasobów działu opraw i katalogów - kartoteki, dokumentacja jednostki jak i prace bibliograficzne oraz 22750 pozostawionych ksiażek: monografie, magazyny o tematyce politycznej i wydawnictwa urzędowe ${ }^{55}$. Tę część depozytu Pruskiej Biblioteki Państwowej niemieccy pracownicy tej instytucji przekazali polskim władzom na początku lipca $1945 \mathrm{r}$. Po wykonaniu tego zadania Rudolf Juchhoff i Eugen Paunel powrócili do Berlina (w sierpniu 1945 r.). Zasoby berlińskiej biblioteki zostały przekazane do Zbiornicy Księgozbiorów Zabezpieczonych we Wrocławiu ${ }^{56}$. W latach I947-I949 zgromadzono w niej około 900000 tomów różnych niemieckich wydawnictw ${ }^{57}$. Ta masa książek, autografów, druków, gazet i manuskryptów posłużyła później do odbudowy i uzupełnienia zbiorów bibliotecznych wielu polskich placówek. W Archiwum Państwowym w Jeleniej Górze zachowała się jedynie

50 Tamże.

51 Tamże, s. 148.

52 Tamże, s. 149.

53 Tamże.

54 Tamże.

55 Tamże.

56 Sprawozdanie Aleksandra Birkenmajera z wizytacji Biblioteki Uniwersyteckiej we Wrocławiu przeprowadzonej w dniach 14-19 VI 1949 r., Archiwum Akt Nowych, Ministerstwo Oświaty, sygn. 6943, k. 1-36.

57 R. Nowicki, Aleksander Birkenmajer jako wizytator Zbiornicy Księgozbiorów Zabezpieczonych we Wrocławiu, „Biblioteka”, nr 17/2013, s. 139-151. 
korespondencja, wydawnictwa urzędowe i katalogi antykwaryczne będące częścią zasobu Pruskiej Biblioteki Państwowej.

Wojenne i powojenne losy zbiorów Pruskiej Biblioteki Państwowej zdeponowanych w czasie II wojny światowej na Dolnym Śląsku wskazują, że w dalszym ciągu wiemy bardzo niewiele na temat niemieckich kolekcji bibliotecznych, jakie trafiły do polskich zbiorów po 1945 r. Oprócz przechowywanej w Krakowie tzw. „Berlinki” - która stanowi oczywiście najpokaźniejszy depozyt berlińskiej biblioteki - polscy bibliotekarze i muzealnicy odpowiedzialni za powojenną akcję rewindykacyjną z całą pewnością odnaleźli (na tzw. Ziemiach Odzyskanych) wiele innych fragmentów Pruskiej Biblioteki Państwowej. Zasoby tej placówki zdeponowano nie tylko na Dolnym Śląsku, ale również w kilku innych składnicach rozlokowanych na terenie dzisiejszych województw Zachodniopomorskiego i Lubuskiego. Losy kolekcji bibliotecznych ewakuowanych z Berlina do tych składnic (a po wojnie odnalezionych przez polskich urzędników i przechowywanych w Krakowie, Warszawie, Olsztynie, Toruniu, Lublinie i Łodzi) powinny stać się przedmiotem odrębnych badań przeprowadzonych przez historyków i bibliotekarzy.

\section{Repositories of the Berlin State Library collection in Lower Silesia during the World War II Summary}

German cultural institutions had been conducting preparations to secure their collections in the event of a war since mid-I930s. The Prussian State Library, the holdings of which included the most precious German manuscripts and prints, was one of those institutions. Air attacks carried out on the capital of the Third Reich triggered the decision to evacuate the collection to Thüringen, Brandenburg, Pomerania and Lower Silesia. Largest deposits had been located in the latter. The unique heritage items stored there included medieval manuscripts, prayer books, music autographs and newspaper yearbooks as well as letters and private documents of many prominent representatives of German culture and art. Those items were evacuated, among other places, to Fürstenstein (Książ) Gießmannsdorf (Gościszów), Gröditzburg (Grodziec), Grüssau (Krzeszów), Fischbach (Karpniki) and Hirschberg (Jelenia Góra). The evacuation was conducted in cooperation with the heritage conservator for Lower Silesia, professor Günther Grundmann. With his assistance, in the course of a few years, a unique collection was created in Lower Silesia. Towards the end of the war the collection was deprived of proper care, as the authorities lacked resources to secure it. This resulted in the destruction of some items during military actions. The remaining parts of the collection had been taken over by Polish officials and were transferred to library collections in Krakow, Warszawa, Olsztyn, Toruń, Lublin and Łódź.

Keywords: Berlin State Library, Evacuation of cultural goods, Repositories of cultural goods, Silesia, Restitution, Wartime losses

Nota o Autorze: Jarosław Robert Kudelski, badacz i ekspert w zakresie problematyki strat wojennych polskiego dziedzictwa kulturowego, autor i współautor kilkudziesięciu publikacji i książek - w tym „Lista Grundmanna. Tajemnice skarbów Dolnego Śląska” (20I5), „Zaginiony Rafael. Kulisy największej kradzieży nazistów” (20I4), „Zrabowane skarby. Losy dzieł sztuki na ziemiach polskich w czasie II wojny światowej" (20I2) - poświęconych tej tematyce. 